\title{
EFFECTS OF LIGHT REGIMENS AND VITAMIN D3 LEVELS AND THEIR INTERACTIONS ON GROWTH PARAMETERS AND SOME BLOOD PLASMA CONSTITUENTS OF BROILER CHICKENS.
}

\author{
M. A. Metwally, M.F.A. Farghly and T.M. Sharaqa \\ Department of Poultry Production, Faculty of Agriculture, University of Assuit, Assuit, Egypt, 71526
}

(Received 19/1/2021, accepted 23/3/2021)

\section{SUMMARRY}

\begin{abstract}
he present study was designed to investigate the effect of light regimens and vitamin D3 levels on 7 growth performance and some carcass traits of broiler chickens. Two hundred and seventy birds were randomly assigned in factorial design ( $3 \times 3)$. Three light regimens $(24 \mathrm{hrs}$ continues light, 12 hrs continues with $12 \mathrm{hrs}$ flash light and $24 \mathrm{hrs}$ flash light) and three vitamin D3 levels (0 IU Vit. D3, 200IU Vit. D3 and 400IU Vit. D3). Nine treatments of 30 birds each (three replicates of 10 birds each). The results showed that significantly affected body weight, daily weight gain and feed conversion ratio. In addition, birds reared under continuous with flash light and feed with 200 IU Vit. D3 had significantly $(\mathrm{P} \leq 0.05)$ highest in body weight, daily weight gain and feed conversion and some plasma constituents as compared to the other groups. Finally, birds were reared under continuous with flash light and feed with 200IU Vit. D3 was better than the other groups and was recommended to the poultry producer.
\end{abstract}

Keywords: broilers, light regimens, vitamin d3 levels, plasma constituents

\section{INTRODUCTION}

Nelson et al., (2020) observed that birds in the intermittent, short-dawn/dusk photoperiod (ISD) treatment were heavier on day 45 of age. Olanrewaju et al., (2019a) showed that broilers subjected to regular/intermittent photoperiod increased body weight on day 42, of age. .Kheiri and $\operatorname{Landy}(2019)$ reported that final body weight $(\mathrm{BW})$ of broiler chickens supplemented with $1-\alpha(\mathrm{OH}) \mathrm{D} 3$ and 1500 IU of cholecalciferol/ $\mathrm{kg}$ of diet and 1- $\alpha(\mathrm{OH}) \mathrm{D} 3$ and $3000 \mathrm{IU}$ of cholecalciferol/ $\mathrm{kg}$ of diet was greater than those fed basal diet, basal diet supplemented with 1- $\alpha(\mathrm{OH}) \mathrm{D} 3$ alone and basal diet supplemented with 1$\alpha(\mathrm{OH}) \mathrm{D} 3$ and $5000 \mathrm{IU}$ of cholecalciferol $/ \mathrm{kg}$ of diet.

Olanrewaju et al., (2019a) showed that regular/intermittent photoperiod increased body weight gain (BWG) on day 42, and day 56 of age in comparison with short/non-intermittent photoperiod. Abbasi et $a l .$, (2017) reported that the injection of vitamin D3 increased the growth rate of broiler chickens.

Olanrewaju et al., (2019a) showed that broilers reared under short/non-intermittent photoperiod had reduced feed intake on day 14 , day 28 , day 42, and day 56 of age compared with those birds subjected to regular/intermittent photoperiods. Olanrewaju et al., (2018) showed that broilers subjected to the short/non intermittent (8L:16D) photoperiod had the lowest feed consumption compared to other two photoperiods (long/continuous (23L:1D), regular/intermittent (2L:2D)), broilers reared under short/non-

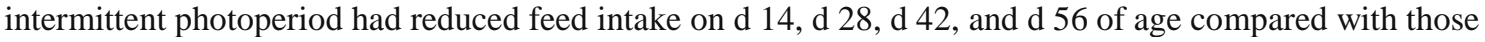
subjected to long/continuous and regular/intermittent photoperiods. Kheiri et al., (2019) illustrated that treatments (dietary 1 alpha-hydroxycholecalciferol) failed to induce any significant effect on daily feed intake (DFI) in quails.

.Farghly et al., (2019b) reported that hens exposed to intermittent lights for $20 \mathrm{~min} / \mathrm{h}+40 \mathrm{~min}$ of constant light had the lowest FCR when compared with the other groups. Arowolo et al., (2019) reported that various degrees of intermittent photo-period (i.e., mixing photo and scoto - periods within 24 hours) rather than one continuous photoperiod have been proven to significantly improve broilers' feed to gain ratio up to $7.3 \%$. Kheiri and Landy (2019) reported that feed conversion ratio of broiler chickens fed basal diet supplemented with $1-\alpha(\mathrm{OH}) \mathrm{D} 3$ and 1500 or $3000 \mathrm{IU}$ of cholecalciferol/kg of diet were significantly 


\section{Metwally et al.}

better than those fed basal diet, basal diet supplemented with 1- $\alpha(\mathrm{OH}) \mathrm{D} 3$ alone or basal diet supplemented with 1- $\alpha(\mathrm{OH}) \mathrm{D} 3$ and $5000 \mathrm{IU}$ of cholecalciferol/ $\mathrm{kg}$ of diet.

Olanrewaju et al., (2013) reported that in comparison with the long/continuous and regular/ intermittent photoperiods, the short/nonintermittent photoperiod significantly reduced triiodothyronine (T3) and total protein (TP).

On the other hand, Farghly et al., (2019b) reported that there were no significant differences in blood parameters (Total proteins, Albumin, Globulin, Albumin: globulin ratio, Cholesterol, AST, ALT and T3) due to the intermittent light among the treated groups. Olanrewaju et al., (2013) reported that there was no photoperiod, light intensity, or photoperiod $\times$ light intensity interaction on blood glucose on any of the sampling days. In addition, there were no effects of treatments on glucose and thyroxine (T4).

Han et al., (2009) reported that $1 \alpha-\mathrm{OH}-\mathrm{D} 3$ facilitate intestinal $\mathrm{P}$ absorption due to stimulating small intestinal NaPi-IIb cotransporter gene expression. Khan et al., (2009) showed that the concentration of Ca and inorganic phosphorus (IP) in the serum was significantly depressed in broilers fed diet contained VIT-D3 200 IU/kg compared with those fed the diets contained its higher levels. Concentrations of these minerals in the serum increased progressively with the level of VIT-D3 supplementation to broiler diets at both 21 and 42 days of age.

On the other hand, Bozkurt et al., (2017) reported that serum ionized $\mathrm{Ca}$ and $\mathrm{Mg}$ concentrations showed no response to the vitamin D diatery. Han et al., (2012) indicated that the dietary $1 \alpha-\mathrm{OH}$ D3 decreased serum Ca concentration. Also, the addition of $1 \alpha-\mathrm{OH}$ D3 showed a trend of increasing serum Pi concentration, but the difference was not significant. Therefore, the objective of this present study was to investigate the influence of lighting programs and vitamin D3 levels on the growth performance and some plasma constituents of broilers.

\section{MATERIALS AND METHODS}

The current study was carried out at the Research Poultry Farm, Faculty of Agriculture, Assiut University, Assiut, Egypt.

\section{Birds, management and experimental design}

270 (two hundred and seventy) one-day old broiler chickens from a common commercial strain (Sasso) were used. Three light regimens, (24hr continues light, C; $12 \mathrm{hr}$ continues light plus $12 \mathrm{hr}$ flash light, CF; and 24hr flash light, F) and three levels of vitamin D3 (Control, $200 \mathrm{ICU}$ and $400 \mathrm{ICU} / \mathrm{Kg}$ ) were used. Based on the conversion of $0.025 \mu \mathrm{g}$ to 1 ICU NRC, 1994. chicks were divided into 9 treatments 30 birds each in three replicates 10 birds each in a factorial design $(3 \times 3)$. Chicks were wingbanded, weighed and housed in 27 rectangular pens $(2 \mathrm{~m} 2)$ the stocking density was $10 \mathrm{birds} / \mathrm{m} 2$ on wheat straw litter floor with $6 \mathrm{Cm}$ deep situated in thermostatically controlled building to provide the required temperature. The chicks were reared under $32{ }^{\circ} \mathrm{C}$ temperature as standard brooding temperature and $55 \%$ relative humidity during the first week, then gradually reduced $2{ }^{\circ} \mathrm{C}$ every three days to reach 24 ${ }^{\circ} \mathrm{C}$ and $55 \%$ relative humidity. The pens were lightproof by using double-layer black curtains on the windows. The light and dark cycles were obtained by using test light source controlled by automatic timer and dimmer to justify lighting periods and light intensity between 5 and 10 lux for each lighting group. Light source was incandescent bulb. Light flashes defined as a twenty light flashes per minute and they were generated by a flasher device that contained a timer and dimmer to justify lighting periods and intensity. Each pen was equipped with a feeder and a drinker. Chicks were provided with as much food and water as they wanted, and feed consumption was calculated at the end of each week. Chicks were provided with commercial feed according to age specifications. All diets were formulated to meet or exceed NRC (1994) recommendations for essential amino acids in starter diet containing (23\% protein, ME $3000 \mathrm{Kcal} . / \mathrm{Kg}$ ) from day one to twenty-one days old of age and grower diet containing $(21 \%$ protein, ME $3100 \mathrm{Kcal}$. /Kg) from twenty-two days to forty-two days old of age (NRC 1994). The design as follow:

Group one (G1): Chicks were exposed to $24 \mathrm{hr}$ of continues light and fed a diet with level one (zero international chick unit of vitamin D3) of vitamin D3.

Group two (G2): Chicks were exposed to $24 \mathrm{hr}$ of continues light and fed a diet with level two (200 international chick unit of vitamin D3) of vitamin D3. 
Group three (G3): Chicks were exposed to $24 \mathrm{hr}$ hours of continues light and fed a diet with level three (400 international chick unit of vitamin D3) of vitamin D3.

Group four (G4): Chicks were exposed to $12 \mathrm{hr}$ continues light plus $12 \mathrm{hr}$ flash light and fed a diet with level one (zero international chick unit of vitamin D3) of vitamin D3.

Group five (G5): Chicks were exposed to $12 \mathrm{hr}$ continues light with $12 \mathrm{hr}$ flash light and fed a diet with level two (200 international chick unit of vitamin D3) of vitamin D3.

Group six (G6): Chicks were exposed to $12 \mathrm{hr}$ continues light with $12 \mathrm{hr}$ flash light and fed a diet with level three (400 international chick unit of vitamin D3) of vitamin D3.

Group seven (G7): Chicks were exposed to $24 \mathrm{hr}$ of flash light and fed a diet with level one (zero international chick unit of vitamin D3) of vitamin D3.

Group eight (G8): Chicks were exposed to 24hr of flash light and fed a diet with level two (200 international chick unit of vitamin D3) of vitamin D3.

Group nine (G9): Chicks were exposed to $24 \mathrm{hr}$ of flash light and fed a diet with level three (400 international chick unit of vitamin D3) of vitamin D3.

\section{Measured criteria:}

Body weights were recorded at six weeks of age. chicks were individually weighed ( \pm 1 gram). Body weight gains (BWG) and feed conversion ratio (FCR) were calculated from one day old to 42 days of age. Feed consumption was determined and calculated as gram feed/bird/day for the same time period.

At the end of the experiment, blood samples were collected after slaughtered in heparinized tubes. Blood samples were centrifuged at 3,000 rpm for $15 \mathrm{~min}$, and plasma obtained was stored at $-20{ }^{\circ} \mathrm{C}$ until analysis. Plasma total protein, albumin, globulin values were obtained by subtracting the values of albumin from the corresponding values of total protein, A/G ratio and glucose. Some hormones and enzymes transaminase enzymes activities (Aspartate aminotransferase (AST) and alanine aminotransferase (ALT)) were determined colorimetrically using available commercial kits purchased from Spectrum Diagnostic Company (Cairo, Egypt), and blood plasma concentrations of triiodothyronine (T3) were determined in blood plasma according to the method of Britton et al., (1975), also, T3/T4 ratio were determined. Cholesterol and total lipids were determined calorimetrically using available commercial kits purchased from Spectrum Diagnostic Company (Cairo, Egypt), also Cholesterol/Lipids ratio were determined. Blood plasma the following elements were measured: calcium $(\mathrm{Ca})$, phosphorus (P) and IP/Ca ratio.

\section{Statistical analysis:}

Data obtained from this study were tested for the significance of lighting treatments effect by ANOVA and GLM using the SAS procedure (version 9.2, 2009). Duncan's multiple range test (1955), was used to determine differences among means when treatment effects were significant. All data percentages of this study were transformed to Arcsine values before analysis. Significant differences were considered to exist when $(\mathrm{P}<0.05)$. The mathematical model used was:

$$
\mathbf{Y i j k}=\boldsymbol{\mu}+\mathbf{L i}+\mathbf{D j}+(\mathbf{L D}) \mathbf{i j}+\mathbf{E} \mathbf{i j k}
$$

Where: Yijk is any observation by lighting programs $\mathrm{Li}$ for ( $\mathrm{i}=1,2$ and 3 ) and vitmin D3 levels Djfor $\mathrm{j}=$ 1,2 and 3. $\mu=$ The population mean. $\mathrm{Li}=$ Lighting programs effect $(\mathrm{i}=1,2$ and 3$) . \mathrm{Dj}=$ Vitamin $\mathrm{D} 3$ levels effect $(\mathrm{j}=1,2$ and 3$)$. (LD)ij= Interaction of lighting programs $\times$ vitamin D3 levels. Eijk= Experimental error.

\section{RESULTS AND DISCUSSION}

\section{Growth performance:}

There were significant differences due to lighting programs at $(\mathrm{P}<0.05)$ (Table 1). Body weight of Sasso broiler chicks which exposed to a continues+flash lighting program were the same significantly affect as the effect of flash lighting program they both were higher than continues lighting programs. Regarding to the effect of vitamin D3 levels, there were significant differences on body weight at $(\mathrm{P} \leq 0.05)$. Chicks which fed on diet with vitamin D3 level 200IU/Kg were the same significantly affect as the effect of 400IU/Kg of Vit.D3 level so level 2 of Vit. D3 and level 3 is better than level one. There was 


\section{Metwally et al.}

significant affect due to the interaction between light program and vitamin D3 levels on body weight.There were significant differences due to lighting programs. However, body weight gains of Sasso broiler chicks which exposed to the continues+flash lighting program were better than the other both continues and flash lighting programs. There were no significant differences on broilers as affected by vitamin D3 levels. However, broilers that had fed on diet with level two of vitamin D3 was significantly equaled with level three of vitamin D3 in the mean gain weeks of age, and they both were higher than the chicks which fed on level one of vitamin D3. There were significant effects due to the interaction between lighting programs and vitamin D3 levels on body weight gain at all ages except the first and second weeks of age. There were no significant differences due to lighting programs and vitamin D3 levels and their interactions on feed consumption. The obtained results are in agreement with Farghly et al., (2019a) who reported that broilers exposed to flashing light had the highest body weight. Using flashing light may have aided early growth by providing more opportunity for the birds to reduce heat production and stimulate the secretory patterns of several hormones (Farghly and Makled, 2015; Farghly et al., 2016). Providing intermittent light for 2L:2D has been shown to improve growth performance compared with 8L:16D (Olanrewaju et al., 2012; Olanrewaju et al., 2019b).

There were significant differences due to lighting programs on in BWG at six weeks of age at $(\mathrm{P} \leq 0.05)$. There were no significant differences at six weeks of age in BWG as affected by vitamin D3 levels. However, broilers that had fed on diet with level two of vitamin D3 was significantly equaled with level three of vitamin D3 in the mean gain weeks of age, and they both were higher than the chicks which fed on level one of vitamin D3. There were significant effects due to the interaction between lighting programs and vitamin D3 levels on body weight gain at six weeks of age. These results are in equal with Farghly et al., (2019a) reported that broilers exposed to flashing light regime had the highest BWG. Also, Olanrewaju et al., (2019a) who showed that regular/intermittent photoperiod increased BWG on day 14, day 28 , day 42 , and day 56 of age in comparison with short/non-intermittent photoperiod

The results of feed conversion ratio as affected by light regimens and vitamin D3 levels and their interactions presented in (Table 2). Feed conversion ratio of Sasso broiler chicks which exposed to a flash lighting and continues+flash lighting programs were the best lighting program. The rest of the other ages had no significant effects. Chicks which fed on diet with level 2 and 3 of vitamin D3 were the same significantly effect. Level 2 and 3 of Vit. D3 was better than the level 1. While, the rest of the other ages had no significant effects. The groups were raised under the continues+flash lighting program, flash program and fed on diet with level two and three of vitamin D3 were better than the other treatments. Our study in agreement with Farghly et al., (2019a) who reported that broilers exposed to flashing light regime had the lowest FCR. There were significant differences due to lighting programs at the mean FCR. However, feed conversion ratio of Sasso broiler chicks which exposed to a flash lighting and continues+flash lighting programs were the best lighting program. Regarding to the effect of vitamin D3 levels, there were significant differences on feed conversion ratio at the mean FCR. Chicks which fed on diet with level 2 and 3 of vitamin D3 were the same significantly effect. Level 2 and 3 of Vit. D3 was better than the level one.

\section{Some plasma constituents:}

The effects of lighting programs, vitamin D3 levels and their interactions on some plasma constituents of Sasso broiler chicks are presented in Table (2).

It could be observed that there were significant differences in glucose of plasma constituents due to the effects of lighting programs at significant $\mathrm{P} \leq 0.0093$. Chicks which raised under continues+flash lighting program were significantly affected on glucose they were higher than chicks which raised under the other lighting programs.No significant differences were observed for plasma constituents of treated chicks by vitamin D3 levels. There were insignificant effects due to the interactions' effects between lighting programs and vitamin D3 levels on plasma constituents.

These findings partially agree with Farghly et al., (2019b) reported that there were no significant differences in blood parameters (Total proteins, Albumin, Globulin and Albumin: globulin ratio) due to the intermittent light among the treated groups (First group non-treated control exposed to continuous and constant light for $16 \mathrm{~h} \mathrm{light/day,} \mathrm{second} \mathrm{group} \mathrm{intermittent} \mathrm{lights} \mathrm{for} 20 \mathrm{~min} / \mathrm{h}+40 \mathrm{~min}$ of constant light and $40 \mathrm{~min} / \mathrm{h}+20 \mathrm{~min}$ of constant light during the $16 \mathrm{~h}$ of light period.). And, El-Fikyet al., (2008) who postulated that total protein concentrations were not different among the different lighting regimes. 
Table (1): Effects of lighting programs, vitamin D3 levels and their interactions on the performance of broiler chickens from one day old to final body weight at $\mathbf{4 2}$ days of age.

\begin{tabular}{|c|c|c|c|c|}
\hline Treatment & $\begin{array}{c}\text { Body weight } \\
\text { (g) }\end{array}$ & $\begin{array}{l}\text { Body weight gain } \\
\text { (g) }\end{array}$ & $\begin{array}{l}\text { Feed consumption } \\
\qquad(\mathrm{g})\end{array}$ & $\begin{array}{c}\text { Feed conversion } \\
\text { Ratio }\end{array}$ \\
\hline \multicolumn{5}{|l|}{ Lighting programs } \\
\hline Continues (C) & $1231.61 \pm 10.52^{b}$ & $1144 \pm 17^{\mathrm{b}}$ & $2166.3 \pm 27$ & $1.81 \pm 0.03^{\mathrm{a}}$ \\
\hline Continues+Flash & $1329.00 \pm 7.22^{\mathrm{a}}$ & $1273 \pm 10^{\mathrm{a}}$ & $2113 \pm 43$ & $1.65 \pm 0.04^{\mathrm{b}}$ \\
\hline Flash $(\mathrm{F})$ & $1316.98 \pm 8.93^{\mathrm{a}}$ & $1258 \pm 13^{\mathrm{a}}$ & $2078 \pm 20$ & $1.63 \pm 0.03^{\mathrm{b}}$ \\
\hline$P$-value & $<.0001$ & $<.0001$ & 0.1652 & 0.0014 \\
\hline \multicolumn{5}{|l|}{ Vit. D3 levels: } \\
\hline 000 IU level 1 (L1) & $1261.75 \pm 11.35^{\mathrm{b}}$ & $1169 \pm 18^{\mathrm{b}}$ & $2166 \pm 32$ & $1.79 \pm 0.04^{\mathrm{a}}$ \\
\hline 200 IU level 2 (L2) & $1303.57 \pm 10.07^{\mathrm{a}}$ & $1240 \pm 14^{\mathrm{a}}$ & $2116 \pm 38$ & $1.65 \pm 0.04^{\mathrm{b}}$ \\
\hline 400 IU level 3 (L3) & $1311.13 \pm 8.19^{\mathrm{a}}$ & $1266 \pm 9^{\mathrm{a}}$ & $2076 \pm 23$ & $1.64 \pm 0.03^{\mathrm{b}}$ \\
\hline$P$-value & 0.0012 & $<.0001$ & 0.1569 & 0.0092 \\
\hline \multicolumn{5}{|l|}{ Interactions } \\
\hline (G1) C*L1 & $1188.54 \pm 20.10^{\mathrm{d}}$ & $1169 \pm 37^{\mathrm{d}}$ & $2171 \pm 20$ & $1.92 \pm 0.04^{\mathrm{a}}$ \\
\hline (G2) $C^{*} \mathrm{~L} 2$ & $1241.62 \pm 21.53^{c}$ & $1153 \pm 29^{c}$ & $2233 \pm 40$ & $1.78 \pm 0.03^{\mathrm{b}}$ \\
\hline (G3) $\mathrm{C} * \mathrm{~L} 3$ & $1255.76 \pm 9.52^{c}$ & $1210 \pm 11^{\mathrm{bc}}$ & $2095 \pm 48$ & $1.72 \pm 0.03^{\mathrm{bc}}$ \\
\hline (G4) $\mathrm{CF} * \mathrm{~L} 1$ & $1304.00 \pm 14.39^{\mathrm{ab}}$ & $1220 \pm 24^{\mathrm{bc}}$ & $2189 \pm 101$ & $1.75 \pm 0.08^{\mathrm{b}}$ \\
\hline (G5) $\mathrm{CF}^{*} \mathrm{~L} 2$ & $1333.83 \pm 10.77^{\mathrm{a}}$ & $1294 \pm 10^{\mathrm{a}}$ & $2058 \pm 72$ & $1.59 \pm 0.04^{\mathrm{c}}$ \\
\hline (G6) $\mathrm{CF}^{*} \mathrm{~L} 3$ & $1345.00 \pm 11.90^{\mathrm{a}}$ & $1306 \pm 11^{\mathrm{a}}$ & $2091 \pm 47$ & $1.60 \pm 0.04^{\mathrm{c}}$ \\
\hline (G7) $\mathrm{F}^{*} \mathrm{~L} 1$ & $1284.16 \pm 17.19^{\mathrm{bc}}$ & $1218 \pm 25^{\mathrm{bc}}$ & $2137 \pm 33$ & $1.71 \pm 0.04^{\mathrm{bc}}$ \\
\hline$(\mathrm{G} 8) \mathrm{F}^{*} \mathrm{~L} 2$ & $1334.21 \pm 12.79^{\mathrm{a}}$ & $1273 \pm 25^{\mathrm{ab}}$ & $2056 \pm 16$ & $1.59 \pm 0.03^{\mathrm{c}}$ \\
\hline (G9) $F^{*} \mathrm{~L} 3$ & $1331.45 \pm 14.95^{\mathrm{a}}$ & $1282 \pm 17^{\mathrm{ab}}$ & $2042 \pm 30$ & $1.58 \pm 0.01^{\mathrm{c}}$ \\
\hline$P$-value & $<.0001$ & $<.0001$ & 0.1794 & 0.0003 \\
\hline
\end{tabular}

Table (2): Effects of lighting programs, vitamin D3 levels and their interactions on some plasma constituents of broiler chicks.

\begin{tabular}{|c|c|c|c|c|c|}
\hline \multirow[t]{2}{*}{ Treatments } & Some nlasma constituents & & & & \multirow[b]{2}{*}{ Glucose } \\
\hline & Total protein & Albumin & Globulin & A/G ratio & \\
\hline Lighting nrograms: & & & & & \\
\hline Continues (C) & $4.13 \pm 0.09$ & $1.70 \pm 0.09$ & $2.42 \pm 0.04$ & $0.71 \pm 0.04$ & $16.29 \pm 0.42 b$ \\
\hline Continues+Flash (CF) & $4.27 \pm 0.10$ & $1.72 \pm 0.08$ & $2.56 \pm 0.04$ & $0.67 \pm 0.03$ & $17.85 \pm 0.37 \mathrm{a}$ \\
\hline Flash $(\mathrm{F})$ & $4.22 \pm 0.07$ & $1.79 \pm 0.07$ & $2.43 \pm 0.06$ & $0.74 \pm 0.04$ & $16.38 \pm 0.29 b$ \\
\hline$P$ - value & 0.4807 & 0.7244 & 0.1207 & 0.4751 & 0.0093 \\
\hline Vit. D3 levels: & & & & & \\
\hline 000 IU level 1 (L1) & $4.20 \pm 0.08$ & $1.77 \pm 0.08$ & $2.44 \pm 0.05$ & $0.73 \pm 0.04$ & $16.73 \pm 0.48$ \\
\hline 200 IU level 2 (L2) & $4.17 \pm 0.10$ & $1.68 \pm 0.09$ & $2.50 \pm 0.07$ & $0.68 \pm 0.05$ & $16.71 \pm 0.43$ \\
\hline 400 IU level 3 (L3) & $4.24 \pm 0.08$ & $1.77 \pm 0.08$ & $2.48 \pm 0.04$ & $0.72 \pm 0.03$ & $17.08 \pm 0.42$ \\
\hline$P$-value & 0.8545 & 0.6746 & 0.6984 & 0.6629 & 0.7980 \\
\hline Interactions: & & & & & \\
\hline (G1) C*L1 & $4.10 \pm 0.16$ & $1.75 \pm 0.18$ & $2.34 \pm 0.02$ & $0.75 \pm 0.08$ & $15.96 \pm 0.82$ \\
\hline (G2) $C^{*} \mathrm{~L} 2$ & $4.10 \pm 0.16$ & $1.64 \pm 0.20$ & $2.46 \pm 0.07$ & $0.67 \pm 0.10$ & $16.24 \pm 0.95$ \\
\hline (G3) C*L3 & $4.18 \pm 0.19$ & $1.72 \pm 0.15$ & $2.47 \pm 0.10$ & $0.70 \pm 0.07$ & $16.66 \pm 0.67$ \\
\hline (G4) $\mathrm{CF}^{*} \mathrm{~L} 1$ & $4.21 \pm 0.19$ & $1.62 \pm 0.12$ & $2.59 \pm 0.08$ & $0.62 \pm 0.03$ & $17.97 \pm 0.81$ \\
\hline (G5) $\mathrm{CF} * \mathrm{~L} 2$ & $4.29 \pm 0.25$ & $1.70 \pm 0.22$ & $2.58 \pm 0.03$ & $0.66 \pm 0.08$ & $17.59 \pm 0.74$ \\
\hline (G6) $\mathrm{CF}^{*} \mathrm{~L} 3$ & $4.32 \pm 0.10$ & $1.83 \pm 0.12$ & $2.49 \pm 0.09$ & $0.74 \pm 0.06$ & $18.00 \pm 0.65$ \\
\hline (G7) $F^{*} \mathrm{~L} 1$ & $4.30 \pm 0.06$ & $1.93 \pm 0.10$ & $2.37 \pm 0.04$ & $0.81 \pm 0.06$ & $16.26 \pm 0.53$ \\
\hline (G8) $F^{*} \mathrm{~L} 2$ & $4.14 \pm 0.13$ & $1.69 \pm 0.12$ & $2.45 \pm 0.20$ & $0.71 \pm 0.11$ & $16.29 \pm 0.37$ \\
\hline (G9) $F^{*} \mathrm{~L} 3$ & $4.23 \pm 0.17$ & $1.76 \pm 0.17$ & $2.47 \pm 0.05$ & $0.71 \pm 0.07$ & $16.59 \pm 0.76$ \\
\hline$P$ - value & 0.9704 & 0.9172 & 0.5890 & 0.7937 & 0.3413 \\
\hline
\end{tabular}




\section{Some hormones and enzymes:}

The effects of lighting programs, vitamin D3 levels and their interactions on some hormones and enzymes of Sasso broiler chicks are presented in Table (3).

There were significant effects due to the lighting programs on some hormones and enzymes of Sasso chicks. Chicks raised under continues and flash lighting programs they were higher levels in AST and ALT at significant $\mathrm{P} \leq 0.0168$, and $\mathrm{P} \leq 0.0002$ respectively, than other lighting program. Chicks raised under continues+flash and flash lighting programs they were higher levels in T3 at significant $\mathrm{P} \leq 0.0016$ than other lighting program. Chicks raised under continues+flash lighting program they were higher level in $\mathrm{T} 4$ at significant $\mathrm{P} \leq 0.0002$ than other lighting programs. No significant differences were observed for $\mathrm{T} 3 / \mathrm{T} 4$ ratio due to lighting program.

No significant differences were observed for some hormones and enzymes of treated chicks by vitamin D3 levels.

There were no significant effects on some hormones and enzymes of Sasso broiler chicks due to the interactions between lighting programs and vitamin D3 levels except ALT, T3 and T4 at significant $\mathrm{P} \leq 0.0300, \mathrm{P} \leq 0.0282$ and $\mathrm{P} \leq 0.0111$ respectively.

These findings partially agree with Farghly et al., (2019b) who reported that there were no significant differences in blood parameters and T3 due to the intermittent light among the treated groups (First group non-treated control exposed to continuous and constant light for $16 \mathrm{~h} \mathrm{light/day,} \mathrm{second} \mathrm{group} \mathrm{intermittent}$ lights for $20 \mathrm{~min} / \mathrm{h}+40 \mathrm{~min}$ of constant light and $40 \mathrm{~min} / \mathrm{h}+20 \mathrm{~min}$ of constant light during the $16 \mathrm{~h}$ of light period.).

It has been stated that $\mathrm{T} 3$ is the major thyroid hormone regulating oxygen consumption and a metabolically more active substance than T4 (Olanrewaju et al., 2013).

Table (3): Effects of lighting programs, vitamin D3 levels and their interactions on some hormones and enzymes of broiler chicks.

\begin{tabular}{|c|c|c|c|c|c|}
\hline \multirow[t]{2}{*}{ Treatment } & \multicolumn{5}{|c|}{ Some hormones and enzyme } \\
\hline & AST & ALT & T3 & T4 & T3/T4 ratio \\
\hline \multicolumn{6}{|l|}{ Lighting programs: } \\
\hline Continues $(\mathrm{C})$ & $36.28 \pm 1.47^{\mathrm{ab}}$ & $13.17 \pm 0.54^{\mathrm{a}}$ & $369.10 \pm 14.67^{\mathrm{b}}$ & $643.89 \pm 12.91^{\mathrm{b}}$ & $0.57 \pm 0.02$ \\
\hline Continues+Flash & $33.13 \pm 1.06^{\mathrm{b}}$ & $10.46 \pm 0.40^{\mathrm{b}}$ & $438.73 \pm 11.72^{\mathrm{a}}$ & $715.56 \pm 13.06^{\mathrm{a}}$ & $0.61 \pm 0.02$ \\
\hline Flash $(\mathrm{F})$ & $38.18 \pm 0.84^{\mathrm{a}}$ & $13.69 \pm 0.51^{\mathrm{a}}$ & $407.06 \pm 8.78^{\mathrm{a}}$ & $647.22 \pm 7.88^{\mathrm{b}}$ & $0.63 \pm 0.01$ \\
\hline$P$-value & 0.0168 & 0.0002 & 0.0016 & 0.0002 & 0.0889 \\
\hline \multicolumn{6}{|l|}{ Vit. D3 levels: } \\
\hline 000 IU level 1 & $37.36 \pm 1.11$ & $12.85 \pm 0.80$ & $386.78 \pm 20.14$ & $648.89 \pm 12.63$ & $0.59 \pm 0.02$ \\
\hline 200 IU level 2 & $35.70 \pm 1.37$ & $12.27 \pm 0.64$ & $410.00 \pm 9.04$ & $676.11 \pm 17.69$ & $0.61 \pm 0.02$ \\
\hline $400 \mathrm{IU}$ level 3 & $34.52 \pm 1.42$ & $12.20 \pm 0.61$ & $418.11 \pm 13.41$ & $681.67 \pm 16.09$ & $0.61 \pm 0.01$ \\
\hline$\stackrel{P}{P}-$ value & 0.3209 & 0.7705 & 0.3218 & 0.3011 & 0.7629 \\
\hline \multicolumn{6}{|l|}{ Interactions: } \\
\hline (G1) $C^{*} \mathrm{~L} 1$ & $38.26 \pm 2.30$ & $14.17 \pm 1.36^{\mathrm{a}}$ & $333.00 \pm 32.59^{\mathrm{b}}$ & $623.33 \pm 17.64^{\mathrm{b}}$ & $0.53 \pm 0.04$ \\
\hline$(\mathrm{G} 2) \mathrm{C}^{*} \mathrm{~L} 2$ & $36.33 \pm 2.40$ & $12.65 \pm 0.81^{\mathrm{ab}}$ & $389.33 \pm 13.35^{\mathrm{ab}}$ & $653.00 \pm 28.75^{\mathrm{b}}$ & $0.60 \pm 0.05$ \\
\hline (G3) $\mathrm{C} * \mathrm{~L} 3$ & $34.24 \pm 3.29$ & $12.69 \pm 0.51^{\mathrm{ab}}$ & $384.98 \pm 18.93^{\mathrm{ab}}$ & $655.33 \pm 23.31^{\mathrm{b}}$ & $0.59 \pm 0.01$ \\
\hline (G4) $\mathrm{CF}^{*} \mathrm{~L} 1$ & $35.17 \pm 1.99$ & $10.62 \pm 1.22^{\mathrm{b}}$ & $437.33 \pm 27.82^{\mathrm{a}}$ & $686.67 \pm 21.86^{\mathrm{ab}}$ & $0.64 \pm 0.04$ \\
\hline (G5) $\mathrm{CF}^{*} \mathrm{~L} 2$ & $32.27 \pm 2.24$ & $10.48 \pm 0.46^{\mathrm{b}}$ & $429.33 \pm 18.52^{\mathrm{a}}$ & $723.33 \pm 26.03^{\mathrm{a}}$ & $0.60 \pm 0.04$ \\
\hline (G6) $\mathrm{CF}^{*} \mathrm{~L} 3$ & $31.96 \pm 1.22$ & $10.28 \pm 0.40^{\mathrm{b}}$ & $449.52 \pm 20.68^{\mathrm{a}}$ & $736.67 \pm 14.81^{\mathrm{a}}$ & $0.61 \pm 0.02$ \\
\hline (G7) $\mathrm{F}^{*} \mathrm{~L} 1$ & $38.65 \pm 1.35$ & $13.75 \pm 0.80^{\mathrm{a}}$ & $390.00 \pm 17.32^{\mathrm{ab}}$ & $636.67 \pm 3.33^{\mathrm{b}}$ & $0.61 \pm 0.03$ \\
\hline (G8) F*L2 & $38.51 \pm 1.26$ & $13.67 \pm 1.20^{\mathrm{a}}$ & $411.33 \pm 7.69^{\mathrm{a}}$ & $652.00 \pm 24.03^{\mathrm{b}}$ & $0.63 \pm 0.02$ \\
\hline (G9) F*L3 & $37.37 \pm 2.13$ & $13.65 \pm 1.00^{\mathrm{a}}$ & $419.83 \pm 18.14^{\mathrm{a}}$ & $653.00 \pm 8.50^{\mathrm{b}}$ & $0.64 \pm 0.03$ \\
\hline$P$-value & 0.2199 & 0.0300 & 0.0282 & 0.0111 & 0.4186 \\
\hline
\end{tabular}




\section{Cholesterol and total lipids:}

The effects of lighting programs, vitamin D3 levels and their interactions on cholesterol and total lipids of Sasso broiler chicks are presented in Table (4).

There were significant effects due to the lighting programs on cholesterol and total lipids of Sasso chicks. Chicks raised under continues and flash lighting programs they were higher levels in cholesterol at significant $\mathrm{P} \leq 0.0030$ than other lighting program. Chicks raised under flash lighting program they were higher level in total lipids at significant $\mathrm{P} \leq 0.0235$ than other lighting programs. Chicks raised under continues lighting program they were higher levels in cholesterol/lipids at significant $\mathrm{P} \leq 0.0405$ than other lighting programs.

No significant differences were observed for cholesterol, total lipids and cholesterol/total lipids of treated chickens by vitamin D3 levels.

There were no significant effects on cholesterol, total lipids and cholesterol/total lipids due to interactions between lighting programs and vitamin D3 levels.

These findings partially agree with Farghly et al., (2016) indicated that there were significant differences in cholesterol concentration due to lighting regimes. Olanrewaju et al., (2013) reported that continuous exposure of broiler chickens to varying lighting regimes had a minor impact on blood parameters, whereas short photoperiod markedly affected most blood parameters without inducing physiological stress in broilers. On the other hand, El-Fiky et al., (2008) postulated that cholesterol concentrations were not different among the different lighting regimes.

Table (4): Effects of lighting programs, vitamin D3 levels and their interactions on cholesterol and total lipids of broiler chicks.

\begin{tabular}{|c|c|c|c|}
\hline \multirow[t]{2}{*}{ Treatment } & \multicolumn{3}{|c|}{ Cholesterol and total lipid } \\
\hline & Cholesterol & Total lipids & Cholesterol/Lipids \\
\hline \multicolumn{4}{|l|}{ Lighting programs: } \\
\hline Continues (C) & $167.62 \pm 3.50^{\mathrm{a}}$ & $521.33 \pm 14.20^{\mathrm{ab}}$ & $0.32 \pm 0.00^{\mathrm{a}}$ \\
\hline Continues+Flash $(\mathrm{CF})$ & $153.94 \pm 3.71^{\mathrm{b}}$ & $507.33 \pm 6.70^{\mathrm{b}}$ & $0.30 \pm 0.01^{\mathrm{b}}$ \\
\hline Flash (F) & $171.67 \pm 2.92^{\mathrm{a}}$ & $548.28 \pm 6.98^{\mathrm{a}}$ & $0.31 \pm 0.00^{\mathrm{ab}}$ \\
\hline$P$ - value & 0.0030 & 0.0235 & 0.0405 \\
\hline \multicolumn{4}{|l|}{ Vit. D3 supplements*: } \\
\hline 000 IU level 1 (L1) & $168.06 \pm 4.87$ & $526.67 \pm 14.84$ & $0.32 \pm 0.01$ \\
\hline 200 IU level 2 (L2) & $163.44 \pm 3.82$ & $525.11 \pm 9.64$ & $0.31 \pm 0.01$ \\
\hline 400 IU level 3 (L3) & $161.72 \pm 3.89$ & $525.17 \pm 9.50$ & $0.31 \pm 0.00$ \\
\hline$P$-value & 0.5550 & 0.9942 & 0.2993 \\
\hline \multicolumn{4}{|l|}{ Interactions: } \\
\hline (G1) $\mathrm{C} * \mathrm{~L} 1$ & $174.52 \pm 8.29$ & $540.00 \pm 37.86$ & $0.32 \pm 0.01$ \\
\hline$(\mathrm{G} 2) \mathrm{C}^{*} \mathrm{~L} 2$ & $165.67 \pm 3.84$ & $505.67 \pm 14.62$ & $0.33 \pm 0.00$ \\
\hline (G3) C*L3 & $162.67 \pm 5.04$ & $518.33 \pm 21.67$ & $0.31 \pm 0.00$ \\
\hline (G4) $\mathrm{CF}^{*} \mathrm{~L} 1$ & $157.88 \pm 9.63$ & $491.67 \pm 10.14$ & $0.32 \pm 0.01$ \\
\hline (G5) $\mathrm{CF} * \mathrm{~L} 2$ & $151.33 \pm 4.91$ & $519.33 \pm 10.48$ & $0.29 \pm 0.00$ \\
\hline (G6) $\mathrm{CF}^{*} \mathrm{~L} 3$ & $152.61 \pm 6.06$ & $511.00 \pm 11.15$ & $0.30 \pm 0.01$ \\
\hline (G7) F*L1 & $171.78 \pm 6.63$ & $548.33 \pm 13.02$ & $0.31 \pm 0.01$ \\
\hline$(\mathrm{G} 8) \mathrm{F}^{*} \mathrm{~L} 2$ & $173.33 \pm 3.38$ & $550.33 \pm 16.33$ & $0.32 \pm 0.01$ \\
\hline (G9) $F^{*} L 3$ & $169.89 \pm 6.61$ & $546.17 \pm 12.02$ & $0.31 \pm 0.01$ \\
\hline$P$-value & 0.1157 & 0.2868 & 0.0794 \\
\hline
\end{tabular}

${ }^{a-b}$ Means in the same columns in each classification with different superscript are significantly different $P \leq 0.05$.

\section{Blood calcium and phosphors:}

The effects of lighting programs, vitamin D3 levels and their interactions on blood calcium and phosphors of Sasso broiler chicks are presented in Table (5). There were no significant effects on blood calcium and phosphors due to lighting programs. There were significant effects due to vitamin D3 levels on blood calcium and phosphors of Sasso chicks. Chicks which fed on diet with level 2 and 3 of vitamin D3 were the same significantly effect on phosphors level, and level 3 of Vit. D3 was higher than chicks 


\section{Metwally et al.}

which fed on diet with level 1 of vit. D3 at significant $\mathrm{P} \leq 0.0055$. Chicks which fed on diet with level 2 and 3 of vitamin D3 were the same significantly effect on calcium level they were higher than chicks which fed on diet with level 1 of vit. D3 at significant $\mathrm{P} \leq 0.0001$. Regarding with phosphors/calcium there were no significant effects due to vitamin D3 levels. There were no significant effects on phosphors, calcium and phosphors/calcium due to interactions between lighting programs and vitamin D3 levels.

Same results with Adhikari et al., (2020) who showed that $\mathrm{Ca}$ and $\mathrm{P}$ utilization were increased by different forms of vitamin D in the diets. Delezieet al., (2012) reported that supplementation of vitamin $\mathrm{D} 3$ in the diet increased retention of $\mathrm{Ca}$ and $\mathrm{P}$ in broilers. Around $80 \%$ of the inorganic $\mathrm{P}$ is used for the bone mineralization and the rest in the formation of nucleic acids, nucleotides, phospholipids, and phosphorylated proteins (Proszkowiec-Weglarz and Angel, 2013).

Table (5): Effects of lighting programs, vitamin D3 levels and their interactions on blood calcium and phosphors of broiler chicks.

\begin{tabular}{|c|c|c|c|}
\hline \multirow[t]{2}{*}{ Treatment } & \multicolumn{3}{|c|}{ Blood calcium and phosphors } \\
\hline & Phosphors & Calcium & IP/Ca ratio \\
\hline \multicolumn{4}{|l|}{ Lighting programs: } \\
\hline Continues (C) & $6.05 \pm 0.31$ & $8.06 \pm 0.32$ & $0.75 \pm 0.02$ \\
\hline Continues+Flash (CF) & $6.16 \pm 0.20$ & $8.29 \pm 0.34$ & $0.75 \pm 0.02$ \\
\hline Flash (F) & $5.98 \pm 0.28$ & $8.37 \pm 0.37$ & $0.72 \pm 0.02$ \\
\hline$P$-value & 0.8892 & 0.7957 & 0.4834 \\
\hline \multicolumn{4}{|l|}{ Vit. D3 levels: } \\
\hline 000 IU level 1 (L1) & $5.53 \pm 0.20^{\mathrm{b}}$ & $7.32 \pm 0.22^{\mathrm{b}}$ & $0.76 \pm 0.02$ \\
\hline 200 IU level 2 (L2) & $6.02 \pm 0.21^{\mathrm{ab}}$ & $8.36 \pm 0.21^{\mathrm{a}}$ & $0.72 \pm 0.02$ \\
\hline 400 IU level 3 (L3) & $6.64 \pm 0.24^{\mathrm{a}}$ & $9.04 \pm 0.27^{\mathrm{a}}$ & $0.74 \pm 0.02$ \\
\hline$P$ - value & 0.0055 & 0.0001 & 0.5214 \\
\hline \multicolumn{4}{|l|}{ Interactions: } \\
\hline (G1) C*L1 & $5.34 \pm 0.57$ & $7.21 \pm 0.49^{\mathrm{b}}$ & $0.74 \pm 0.04$ \\
\hline$(\mathrm{G} 2) \mathrm{C}^{*} \mathrm{~L} 2$ & $6.24 \pm 0.51$ & $8.55 \pm 0.41^{\mathrm{ab}}$ & $0.73 \pm 0.04$ \\
\hline (G3) $C^{*} \mathrm{~L} 3$ & $6.57 \pm 0.44$ & $8.41 \pm 0.51^{\mathrm{ab}}$ & $0.78 \pm 0.02$ \\
\hline (G4) $\mathrm{CF}^{*} \mathrm{~L} 1$ & $5.72 \pm 0.23$ & $7.43 \pm 0.42^{\mathrm{b}}$ & $0.77 \pm 0.05$ \\
\hline (G5) $\mathrm{CF}^{*} \mathrm{~L} 2$ & $6.30 \pm 0.13$ & $8.27 \pm 0.42^{\mathrm{ab}}$ & $0.76 \pm 0.02$ \\
\hline (G6) $\mathrm{CF}^{*} \mathrm{~L} 3$ & $6.47 \pm 0.48$ & $9.18 \pm 0.50^{\mathrm{a}}$ & $0.71 \pm 0.04$ \\
\hline (G7) $F^{*} \mathrm{~L} 1$ & $5.53 \pm 0.29$ & $7.32 \pm 0.41^{\mathrm{b}}$ & $0.76 \pm 0.04$ \\
\hline (G8) $F^{*} L 2$ & $5.53 \pm 0.24$ & $8.27 \pm 0.42^{\mathrm{ab}}$ & $0.67 \pm 0.05$ \\
\hline (G9) $F^{*} L 3$ & $6.88 \pm 0.47$ & $9.53 \pm 0.25^{\mathrm{a}}$ & $0.72 \pm 0.03$ \\
\hline$P$ - value & 0.1309 & 0.0131 & 0.5221 \\
\hline
\end{tabular}

Khan et al., (2009) showed that the concentration of Ca and inorganic phosphorus (IP) in the serum was significantly depressed in broilers fed diet contained VIT-D3 200 IU/kg compared with those fed the diets contained its higher levels.

Concentrations of these minerals in the serum increased progressively with the level of VIT-D3 supplementation to broiler diets at 42 days of age. Phosphorus $(\mathrm{P})$ is one of the essential minerals for animal growth and survival. Plasma $P$ levels are mainly regulated by the metabolic pathway that includes parathyroid hormone, Vitamin D3 (VD3), calcitonin, and the associated receptors in the small intestine, bone, and kidneys (Veum, 2010).

\section{CONCLUSIONS}

The results of this study indicated that supplement of vitamin D3 and continuous plus flash lighting program improved growth performance until marketing age. 


\section{ACKNOWLEDGEMENTS}

The author express appreciation for the support from the supervision committee (Prof. Dr. Mohamed Metwally and Prof. Dr. Mohamed Farghly Alm El-Deen) and all staff member of Poultry Production Department, Faculty of Agriculture, Assiut University.

\section{REFERENCES}

Abbasi, T., M. Shakeri, M. Zaghari and H. Kohram. (2017). Growth performance parameters, bone calcification and immune response of in ovo injection of 25-hydroxycholecalciferol and vitamin $\mathrm{K} 3$ in male ross 308 broilers. Theriogenology 90: 260-265.

Adhikari, R., D. White, J. D. House, and W. K. Kim. (2020). Effects of additional dosage of vitamin D3, vitamin D2, and 25-hydroxyvitamin D3 on calcium and phosphorus utilization, egg quality and bone mineralization in laying hens. Poult. Sci. 99: 364-373.

Arowolo, M. A., J.H. He, S.P. He and T.O. Adebowale. (2019). The implication of lighting programmes in intensive broiler production system. W. Poult. Sci. A. 75: 17-28.

Bayram, A. and S. Özkan (2010). Effects of a 16-hour light, 8-hour dark lighting schedule on behavioral traits and performance in male broiler chickens. J. Appl. Poult. Res. 19 :263-273.

Bozkurt, M., S. Yalçin, B. Koçer, A. E. Tüzün, H. Akşit, S. Özkan, M. Uygun, G. Ege, G. Güven and O. Yildiz. (2017). Effects of enhancing vitamin D status by 25-hydroxycholecalciferol supplementation, alone or in combination with calcium and phosphorus, on sternum mineralisation and breast meat quality in broilers. Br. POULT. SCI., 58, 4, 452-461.

Britton, K., V. Quinn, B. Brown, and R. Ekins. (1975). A strategy for thyroid function tests. Br. Med. J. $3: 350-352$.

Cho T. Z. A., Muhammad Bilal Sadiq, PairatSrichana, and Anil Kumar Anal. (2019). Vitamin D3 enhanced intestinal phosphate cotransporter genes in young and growing broilers. Poult. Sci. 99:20412047.

Delezie, E., L. Maertens, and G. Huyghebaert. (2012). Consequences of phosphorus interactions with calcium, phytase, and cholecalciferol on zootechnical performance and mineral retention in broiler chickens. Poult. Sci. 91:2523-2531.

Duncan, D.B. (1955). The multiple range and multiple F.test. Biometric.11: 1-42.

El-Fiky, A., M. Soltan, F. Abdou, S. El-Samra, and B. El-Neney. (2008). Effect of light regime and feeding frequency on some productive, physiological traits and hormonal profiles in broiler chicks. Egypt. Poult. Sci. 28:711-743.

Farghly, M. F. A. and Enas A. M. Ahmad (2018). Growth performance and carcass quality of broilers as affected by light flashes program in relation to dietary vitamin $\mathrm{d} 3$ levels. 4thInternational Conference on Biotechnology Applications in Agriculture, 3-7 April 2018, Hurghada, Egypt. Organized by Faculty of Agriculture, Benha University, Egypt.

Farghly, M. F. A., and M. N. Makled. (2015). Application of intermittent feeding and flash lighting regimens in broiler chickens management. Egypt. J. Nutr. Feeds 18:261-276.

Farghly, M. F. A., M. A. Metwally, R. M. Ali, and M. E. Ghonime. (2016). Effects of light flash and vitamin D3 levels and their interaction on productive and reproductive performance of Dandrawi chickens. Proceedings of the 17th Conference of Egypt Society of Animal Production on Sustainable Livestock Development: Challenges and Opportunities; 2016 Oct 10-13; Sharm El-Sheikh, Egypt.

Farghly, Mohamed F., Khalid M. Mahrose, Enas, A. M. Ahmad, Zaib Ur Rehman and Shengqing Yu. (2019a). Implementation of different feeding regimes and flashing light in broiler chicks. Poult. Sci. $0: 1-9$. 


\section{Metwally et al.}

Farghly, Mohammed F. A., Khalid M. Mahrose, Zaib Ur Rehman, Shengqing Yu, Mostafa G. Abdelfattah, and Osama H. El-Garhy. (2019b). Intermittent lighting regime as a tool to enhance egg production and eggshell thickness in Rhode Island Red laying hens. Poult. Sci. 0:1-7.

Han, J. C., Wang, Y. L., Qu, H. X., Liang, F., Zhang, J. L., Shi, C. X., ... Wang, C. L. (2012). One alphahydroxycholecalciferol improves growth performance, tibia quality, and meat color of broilers fed calcium-and phosphorus-deficient diets. Asian-Aust. J. Anim. Sci. 25: 267-271.

Han, J.C., Ma, K., Wang, J.G., Chen, G.H., Zhang, J.L., Qu, H.X. (2015) Effects of Non-phytate phosphorus and 1a-Hydroxycholecalciferol on growth performance, bone mineralization, and carcass traits of broiler chickens. Braz. J. Poult. Sci. 17: 503-10.

Han, J.C., Yang, X.D., Zhang, L.M., Li, W.L., Zhang, T., Zhang, Z.Y., Ya, J.H., (2009). Effects of $1 \alpha-$ Hydroxycholecalciferol and phytase on growth performance, tibia parameter and meat quality of 1 - to 21-d-old broilers. Asian Aust. J. Anim. Sci. 22: 857-864.

Khan, S. H., R. Shahid, A. A. Mian, R. Sardar and M. A. Anjum. (2009). Effect of the level of cholecalciferol supplementation of broiler diets on the performance and tibial dyschondroplasia. J. Anim. Physiology and Anim. Nutri., 94:584-593.

Kheiri, F. and N. Landy (2019). The effects of dietary 1-alpha-hydroxycholecalciferol individually or in combination with different levels of cholecalciferol on growth performance and tibia criteria in broiler chickens. Liv. Sci. 221: 172-176.

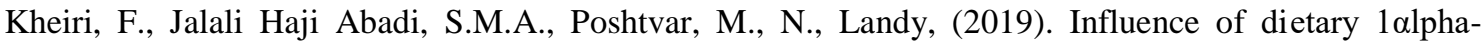
hydroxycholecalciferol, individually or in combination with microbial phytase in calcium and phosphorus deficient diets on performance and tibia parameter of Japanese quails (Coturnix japonica). Acta Sci. Anim. Sci. https://doi.org/10.4025/actascianimsci.v41i1.42540. Accepted.

NRC (1994). Nutrients Requirements of Poultry. 9th ed. National Research Council, National Academy Press, Washington D.C., USA.

Nelson, Jill R., Joey L. Bray, Juliette Delabbio, and Gregory S. Archer. (2020). Comparison of an intermittent, short-dawn/dusk photoperiod with an increasing, long-dawn/dusk photoperiod on broiler growth, stress, and welfare. Poult. Sci. 99:3519-3524.

Olanrewaju, H. A., J. L. Purswell, S. D. Collier, and S. L. Branton. (2013). Interactive effects of photoperiod and light intensity on blood physiological and biochemical reactions of broilers grown to heavy weights. Poult. Sci. 92:1029-1039.

Olanrewaju, H. A., J. L. Purswell, S. D. Collier, and S. L. Branton. (2012). Influence of photoperiod, light intensity, and their interaction on growth performance and carcass characteristics of broilers grown to heavy weights. Int. J. Poult. Sci. 11:739- 746.

Olanrewaju, H. A., S. D. Collier, J. L. Purswell, and S. L. Branton. (2019b). Effects of light-sources and photoperiod on hemato-physiological indices of broilers grown to heavy weights. Poult. Sci. 98:10751082.

Olanrewaju, H. A., W. W. Miller,W. R. Maslin,S. D. Collier,J. L. Purswell, and S. L. Branton. (2019a). Interactive effects of light-sources, photoperiod, and strains on growth performance, carcass characteristics, and health indices of broilers grown to heavy weights. Poult. Sci. 98:6232-6240.

Olanrewaju, H. A., W. W. Miller, W. R. Maslin, S. D. Collier,J. L. Purswell,and S. L. Branton (2018). Influence of light sources and photoperiod on growth performance, carcass characteristics, and health indices of broilers grown to heavy weights. Poult. Sci. 97:1109-1116.

Proszkowiec-Weglarz, M., and R.Angel. (2013).Calciumand phosphorus metabolism in broilers: effect of homeostatic mechanism on calcium and phosphorus digestibility1. J. Appl. Poult. Res. 223:609-627.

SAS. (2009). User's Guide. Version, 9.2, 2002-2009, SAS institute Inc., Cary, NC, USA.

Schwean-Lardner, K., B. I. Fancher, S. Gomis, A. Van Kessel, S. Dalal, and H. L. Classen. (2013). Effect of day length on cause of mortality, leg health, and ocular health in broilers. Poult. Sci. 92:1-11.

Sun, Y.Y., S. Tanga, Y. Chenb, D.L. Lia, Y.L. Bic, D.K. Huaa, C. Chena, Q.Y. Luoa, L. Yanga, J.L. Chen. (2017). Effects of light regimen and nutrient density on growth performance, carcass traits, meat quality, and health of slow-growing broiler chickens. Livestock Sci. 198: 201-208. 
تأثير برامج الإضاءة و مستويات فيتامين دس و التداخل بينهم علبعض مكونات بلازما الدم و أداء نمو دجاج التسمين

\author{
محمد متولى أحمد و محمد فرغلى علم الدين و طه شراقة

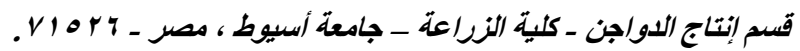

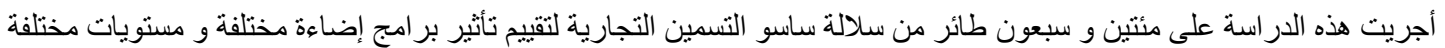

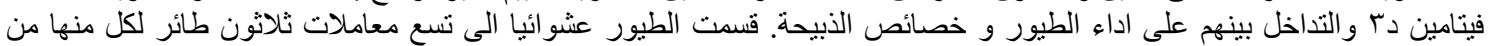

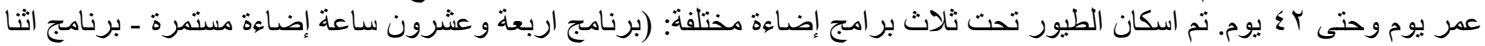

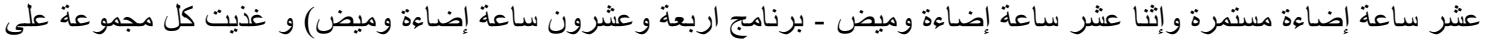

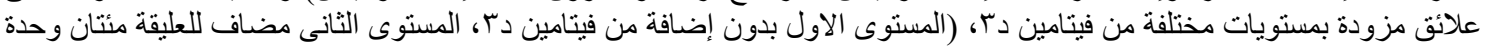

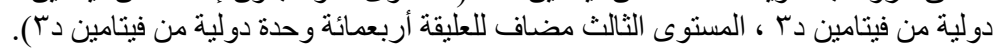

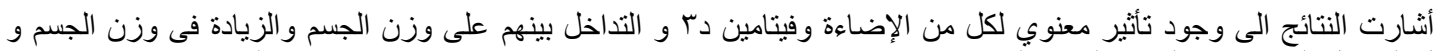

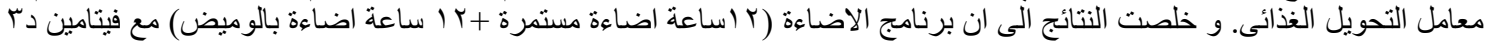

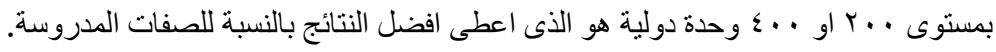

